\title{
University Education in the United States.
}

THE Washington Bureau of Education has just issued Bulletin No. 87, dealing with certain statistics of State universities and colleges in the United States of America for the year ended June 30, 19r9. This is an annual publication which was formerly prepared and published by the National Association of State Universities, and contains data relating to ninety-two public institutions of university rank. The total enrolment in these State institutions for the year 1917-18 was 110,900 , as against 244,23 I in the corresponding private institutions. In 1918-19 the lowest enrolment was $3 I$ for the New Mexico School of Mines, and the highest 8857 for the University of Michigan. With regard to teaching staff, the numbers in the State institutions vary from 7 to 908 , the latter being the number of teachers in the University of Minnesota in 1918-19. It is curious to find that the University of Michigan with its 8857 enrolments shows an average of 20 regular term students per teacher, while the University of Minnesota with an enrolment of 6095 has an average of only 7. What is perhaps more curious is the fact that the total working income of the former is $3,069,5^{87}$ dollars, while that of the latter is $3,462,36$ I dollars.

The fact that the institutions to which the bulletin has reference are passing through a stage of financial stringency very similar to that which is being experienced by the British universities at the present time gives an added interest to the publication. In the American State universities, just as in this country, "the cost of salaries has not risen to the same extent as the cost of living," and, as the bulletin very pertinently says, "unless the people wish to see their higher institutions staffed with men of inferior ability, it will be necessary to pay salaries sufficiently large to attract teachers of merit and ability." University teachers in this country will recognise a familiar ring about this language! The bulletin contains a mass of statistics which have been compiled by the Bureau of Education in the hope that they will be "very useful in the promotion of State campaigns for the more adequate support of higher education." While one may express the hope that American State universities and colleges will receive such public support in the future as will be necessary for their develop. ment, it should be observed that already they receive in the aggregate almost 73 per cent. of their income from public funds. In four States, indeed, the percentage is more than 9o. In this country, notwithstanding the recent additional grant of $500,000 l$. to the universities, State aid is greatly inferior to the State aid which is given to public institutions in America.

Of special interest is the question of students' fees in these universities and colleges. At the outset one must make a clear distinction between public and private universities or colleges in America. The number of students enrolled in the public higher institutions amounts to about $3 \mathrm{r}$ per cent. of the whole, while the remaining 69 per cent. are enrolled in private or non-State-aided institutions. As a rule, the former pay small fees. In the case of New York University the income from fees is as low as 3 per cent. of the total income. The average for the whole country in I9I7-18 was 22 per cent. of the total income. In the private institutions the percentage for the same year varied between $\mathrm{r} 7$ (Connecticut) and 87 (Alabama), with an average of 54 per cent., the remaining income being derived mainly from "productive funds" or private benefactions. So far as the State institutions are concerned there is no indication that students' fees, though lower than those in this country, are to be increased. The campaign to increase the income is apparently to be directed to obtaining increased assistance from public or State funds. The plea for State aid is concisely expressed in the words:- "When the State appropriates money to education, it is making a wise invest. ment which will yield manifold returns. Liberal support of higher education is good public economy and wise forethought for the future." One may be allowed to hope that the Government of this country will ponder over these words. Our home universities are sadly in need of further State aid.

\section{Recent Work on Minerals and Rocks.}

$\mathrm{N}^{\text {ow }}$ W that questions of crystal structure and of approximate isomorphism play so large a part in chemical and physical conceptions, the study of crystallography is no longer for specialists alone. Students of many branches of science will welcome the re-issue of J. B. Jordan's nets for making models of simple crystal-forms (T. Murby and Co., London, $3 s$.$) . The older names can be covered by labels$ bearing those suggested in this edition, though we should like to see "bipyramid" substituted for "pyramid" throughout, since no true pyramids, such as those occurring in tourmaline, are utilised. These models were familiar in the Royal School of Mines forty years ago, and should now. serve many future generations of students whose outlook on crystals has widened with physical research. Their effective colours and their price certainly commend them.

A. D. Hall provides a very interesting memoir (Union of South Africa Geol. Survey, No. I5, I920, $7 s$. 6d.) on "Corundum in the Northern and Eastern Transvaal," in which the modes of occurrence and of working are fully illustrated. The author, in a chapter on "The Problem of Genesis," very properly directs attention to the tardy recognition of corundum as a rock-forming mineral, and lays stress on the experimental work of Morozewicz in I899. Corundum in the Transvaal arises from a granite magma supersaturated with alumina. Hall holds that this supersaturation arises, not through absorption of aluminous material from contact-rocks, but by removal of silica into those rocks along the zones of contact.

In "Phosphate in Canada" (Canada Depart. of Mines, No. 396, I920) Hugh S. Spence describes and illustrates the well-known occurrences of apatite in Ontario and Quebec, and discusses works established in other parts of Canada where imported phosphatic materials are used. The apatite "is to be considered of igneous origin rather than to have been derived from the original limestones "through which the pegmatite masses have passed. The associated minerals, such as pyroxene, scapolite, and phlogopite, are described. At Huddersfield, Quebec, allanite occurs in crystals more than an inch in diameter, and fluorspar, which is here abundant in calcite, assumes a deeper violet colour in close proximity to it. An emanation-influence naturally suggests itself.

The minerals of saline lakes, notably epsomite, are dealt with by L. Reinecke in "Mineral Deposits between Lillooet and Prince George, British Columbia"

NO. 2703 , VOL. IO7] 
(Canada Geol. Survey, Mem. II8, I920). R. Lockhart Jack, in "The Salt and Gypsum Resources of South Australia" (Geol. Surv. S. Australia, Bull. 8, I92I) interestingly connects the salt of the lagoons of the Yorke Peninsula, between Spencer Gulf and the Gulf of St. Vincent, with "cyclic" salt imported aerially during long ages from the sea. The supply thus given to the soil is drawn on by the lakes, with, of course, some addition from salt-dust now falling on their surfaces, and depends on conditions of dryness, whereby the local water-table does not rise dangerously high. The meteorological features of the region are well put forward. The deposits of gypsum are similarly attributed to cyclic matter, which has been redissolved and carried by the saline ground-waters (p. 9o) into lake depressions. On the margins of these it evaporates and becomes blown up into dunes. There are also some occurrences of gypsum in a more normal and less interesting manner in Cainozoic rocks.

The graphite deposits of the world outside the United States are reviewed, with maps, in a valuable paper by A. H. Redfield ("Foreign Graphite in I9ro," U.S. Geol. Surv., Min. Resources, I9I9, part ii., No. I2, I92 I). This pamphlet should stand beside our text-books of mineralogy, which constantly require the refreshing influence of general surveys of this nature. Though the commercial aspect is naturally paramount, the names of localities and the references to literature will be of service to the student.

The work of R. E. Liesegang has added considerably to the interest of zoned and banded deposits. P. A. Wagner (Trans. Geol. Soc. S. Africa, vol. xxiii., p. I 18,1921 ) describes the "Nature and Origin of the Crocodile River Iron Deposits " in the Rustenburg district of the Transvaal. He compares them with those of the Lake Superior region, and holds that the hæmatite and hydroxide masses are concentrations by downward percolation from beds of siderite and ferruginous chert. In some cases alteration in place has led to the formation in chert of magnetite, hæmatite, or brown hydroxide, alike pseudomorphous after rhombohedral siderite.

Olaf Holtedahl (Amer. Journ. Sci., vol. cci., p. I95, 192 I) reviews old and recent work on the zoned concretions of calcite in the magnesian limestone of Durham, pointing out the reasons that have led English geologists to regard them as mineral structures arising through secondary alteration. Their resemblance to some of the pre-Cambrian structures claimed by Walcott as algal (Camasia, Newlandia, Greysonia, etc.) inspires the author with caution in dealing with these older specimens.

Mineralogists cannot afford to overlook the paper by F. W. Clarke and W. C. Wheeler on "The Inorganic Constituents of Marine Invertebrates " (U.S. Geol. Surv., Prof. Paper I02, 1917) with its important series of analyses of the hard parts of a wide range of living creatures. The proportion of magnesium carbonate to calcium carbonate bears, of course, on the much-discussed origin of dolomite, and it is shown that organisms capable of depositing calcite may accumulate magnesium by isomorphous substitution, while this cannot take place when the hard parts are formed of aragonite. The utilisation of magnesium is very distinctly favoured by warm conditions, specimens from Arctic or Antarctic waters, or from very deep waters, showing relatively small proportions. Crinoids, for instance, from $47^{\circ} \mathrm{N}$. lat. and a depth of rooo metres may yield 9 per cent. of magnesium carbonate, while i2 per cent. commonly occurs at similar depths near the equator. A biological problem of much interest is here opened. No such authoritative and detailed analyses have hitherto been available. As was already known, alcyonaria generally are rich in magnesium carbonate. An equatorial specimen of Phyllogorgia quercifolia is here shown to contain 15.73 per cent. The influence of these facts on determinations of specific gravity in fossil forms should, of course, be noted.

The rhyolites of Lipari, including the familiar obsidian of the Rocche Rosse, have received complete and critical examination and analysis from H. S. Washington (Amer. Journ. Sci., fourth series, vol. 1., p. 446,1920$)$. It is shown that in the glassy varieties ferrous oxide predominates largely over ferric oxide, while this condition is reversed in crystalline types. It is suggested that the glassy state retains more nearly the constitution of the igneous magma, while oxidation occurs as the gases are permitted to escape.

W. R. Browne provides a new study of differentiation in an igneous mass, through the sinking of crystals and later extrusions, in his description of "The Igneous Rocks of Encounter Bay, South Australia " (Trans. Roy. Soc. S. Australia, vol. xliv., p. I, I920). In the same volume, p. 300, W. Howchin reviews coarse fragmental structures of various kinds in rocks, citing Australian examples, and he usefully directs attention to the influence of desiccation in breaking up a sediment in an early stage of its history. The drying mud of lakes is an example. Attention may be directed to the moderate price (Ios. 6d.) of this volume and of some other illustrated publications from our federated Commonwealths, in the hope that the enterprise displayed may react on issues in the homeland.
G. A. J. C.

\section{Plant Pests and their Control.}

\section{By Dr. William B. Brierley.}

THE "Report on the Occurrence of Insect and Fungus Pests on Plants in England and Wales for the Year 1919," ${ }^{1}$ which has just been issued by the Intelligence Department--Plant Pests Branch of the Ministry of Agriculture and Fisheries, marks a very definite step in the recognition in this country of the danger to our food crops from diseases caused by insects, fungi, bacteria, etc. This disease-survey work was originated by a sub-committee of the Technical Committee of the late Food Production Department, which was formed to advise the department

1 Ministry of Agriculture and Fisheries. Intelligence Departiment : Plant Pests Branch. (Miscellaneous Publications, No. 33.) "Report on the Occurrence of Insect anit Fungus Pests on Plants in England and Wales for the Year rgrg." Pp. 68. (London: H.M. Stationery Office, r9zr.) is. 6d. net.

NO. 2703 , VOL. IO7] on questions relating to plant disease and insect pests. A few honorary correspondents scattered throughout the country forwarded monthly statements relating to diseases and pests in their own particular areas, and at the close of the year these were summarised by the sub-committee, and a "Report on the Occurrence of Insect and Fungus. Pests during 191; " was published. This was the first time that any successful attempt had been made to gather together and systematise data relating to the incidence and spread of plant disease in this country. With the experience gained the work was continued in a more efficient manner, and a report for I9I8 issued. There has now appeared the present, and somewhat belated, report for r919, and a comparison of these three publications 